\title{
FIRST RECORD OF THE FANGTOOTH MORAY, ENCHELYCORE ANATINA (ACTINOPTERYGII: ANGUILLIFORMES: MURAENIDAE), FROM MALTESE WATERS, CENTRAL MEDITERRANEAN
}

\author{
Alan DEIDUN ${ }^{*}$, David WATSON ${ }^{2}$, Luca CASTRIOTA³, Gianfranco MAZZA ${ }^{4}$, \\ and Linda PASOLLI ${ }^{4}$ \\ ${ }^{1}$ Physical Oceanography Unit, University of Malta, Msida, Malta \\ ${ }^{2}$ Onebreath Freediving, Xemxija, Malta \\ ${ }^{3}$ Institute for Environmental Protection and Research (ISPRA), Palermo, Italy
}

${ }^{4}$ Plemmirio Marine Protected Area, Siracusa, Italy

\begin{abstract}
Deidun A., Watson D., Castriota L., Mazza G., Pasolli L. 2015. First record of the fangtooth moray, Enchelycore anatina (Actinopterygii: Anguilliformes: Muraenidae), from Maltese waters, central Mediterranean. Acta Ichthyol. Piscat. 45 (3): 315-317.
\end{abstract}

\begin{abstract}
The fangtooth moray, Enchelycore anatina (Lowe, 1838), native to the eastern Atlantic Ocean but also known from eastern sections of the Mediterranean, is recorded for the first time from Maltese coastal waters in the central Mediterranean. This record is the westernmost one within the Mediterranean and the observed E. anatina individual co-occurred with an individual of Muraena helena Linnaeus, 1758.
\end{abstract}

Keywords: fish, new record, Atlantic Ocean, non-indigenous species, coastal waters, range-expanding species

The fangtooth moray, Enchelycore anatina (Lowe, 1839), belongs to the family Muraenidae and is a subtropical species, being widely distributed in eastern Atlantic waters, especially within the Lusitanian, Mauretanian, and Senegalese marine biogeographical provinces (i.e., from Portugal to Angola). The species is also known from a number of disparate Atlantic Ocean island groups, such as Azores, Madeira, Canary Islands, Cape Verde, Ascension Island, and St. Helena Islands, as reviewed by Lipej et al. (2011).

Despite its tropical Atlantic origin, within the Mediterranean the species is strangely restricted to areas east of the Sicily Channel. In fact, the species was first caught in the Mediterranean in 1979, off the Israeli coast, at a depth of $50 \mathrm{~m}$ by means of the hook-and-line fishing technique (Ben-Tuvia and Golani 1984). Since then, within the Mediterranean, the species has been exclusively recorded within the eastern and central sectors, being progressively caught or observed from Rhodes and the Elafonissos Islands in Greece, the south-western coast of Turkey, the Syrian coast, Cyprus, and the eastern Adriatic (Croatia). Most recently, additional records of the species have emerged from eastern sectors of the Mediterranean
Sea, such as Iskenderun Bay in Turkey and the island of Zakynthos in the eastern Ionian Sea, suggesting that the species has established itself within these areas, whilst new records of the species are also coming from more central parts of the Mediterranean, indicating the further westward expansion of Enchelycore anatina within the same Basin. Recently, in fact, the species has been reported at numerous additional locations along the eastern Adriatic (Dulčić et al. 2014), along the Italian coast of Puglia (Guidetti et al. 2012) and along the eastern coast of the island of Sicily (Katsanevakis et al. 2014), both in the western Ionian Sea.

This short communication aims to document the further westward expansion within the Mediterranean of Enchelycore anatina and its interaction with the indigenous Muraena helena. In so doing, this study further underpins the importance of the Straits of Sicily as a strategic observatory from where to document changes in species' distributions within the Mediterranean (Azzurro et al. 2014).

The recording of Enchelycore anatina was carried out through visual census from a SCUBA diver who photographed the species and who shot a short video clip of the same species (publicly accessible at YouTube ${ }^{* *}$ ).

* Correspondence: Prof. Alan Deidun, Physical Oceanography Unit, Faculty of Science, Room 315, Chemistry Building 3rd Floor, University of Malta, Msida MSD 2080, Malta, phone: +35623403704, fax: +35621440972, e-mail: (AD) alan.deidun@um.edu.mt, (DW)dmwatson78@gmail.com, (LC) luca.castriota@isprambiente.it, (GM)g.mazza@plemmirio.it, (LP) linda.paso@gmail.com (LP).

** https://www.youtube.com/watch?feature=player_embedded\&v=FEtyn 5 XClFM 
The species was identified according to Bauchot (1987). An individual of Enchelycore anatina was observed in September 2013 in a shallow-water $(12 \mathrm{~m})$ area off the north-western extremity $\left(35^{\circ} 59^{\prime} 18.89^{\prime \prime} \mathrm{N}, 14^{\circ} 19^{\prime} 38.67^{\prime \prime} \mathrm{E}\right)$ of the island of Malta in the central Mediterranean, inside a crevice within a gently-sloping aggregation of rocks and medium-sized (maximum diameter $50 \mathrm{~cm}$ ). Despite only the anterior part of the individual being visible (Fig. 1), the unequivocal colouration of $E$. anatina, consisting of highly prominent yellow blotches/mottles and the long, sharp, fang-like teeth, allow us to distinguish it from the other three moray eel species occurring in the Mediterranean-i.e., brown moray, Gymnothorax unicolor (Delaroche, 1809); reticulated moray, Gymnothorax reticularis Bloch, 1795; and Mediterranean moray, Muraena helena Linnaeus, 1758.

Possibly worth investigating further is the apparently frequent co-occurrence of Enchelycore anatina and $\mathrm{Mu}$ raena helena. This occurrence is evident in the online video clip taken of the same individual, and was also demonstrated by one individual of $E$. anatina recently filmed by one of the Authors (G. Mazza) off the eastern coastline of Sicily (21 October 2014) (Fig. 2), from the same area where the species was previously recorded (Katsanevakis et al. 2014). One may speculate that the co-occurrence of the two species is not coincidental and that some form of synergistic collaboration between the two is taking place, although the hypothesis has not been tested in the field and is simply based on two empirical observations.

The specimen observed in the video from Maltese waters occupied the same hole of two specimens of Muraena helena and showed fearless behaviour in approaching SCUBA divers, compared to the more prudent back and

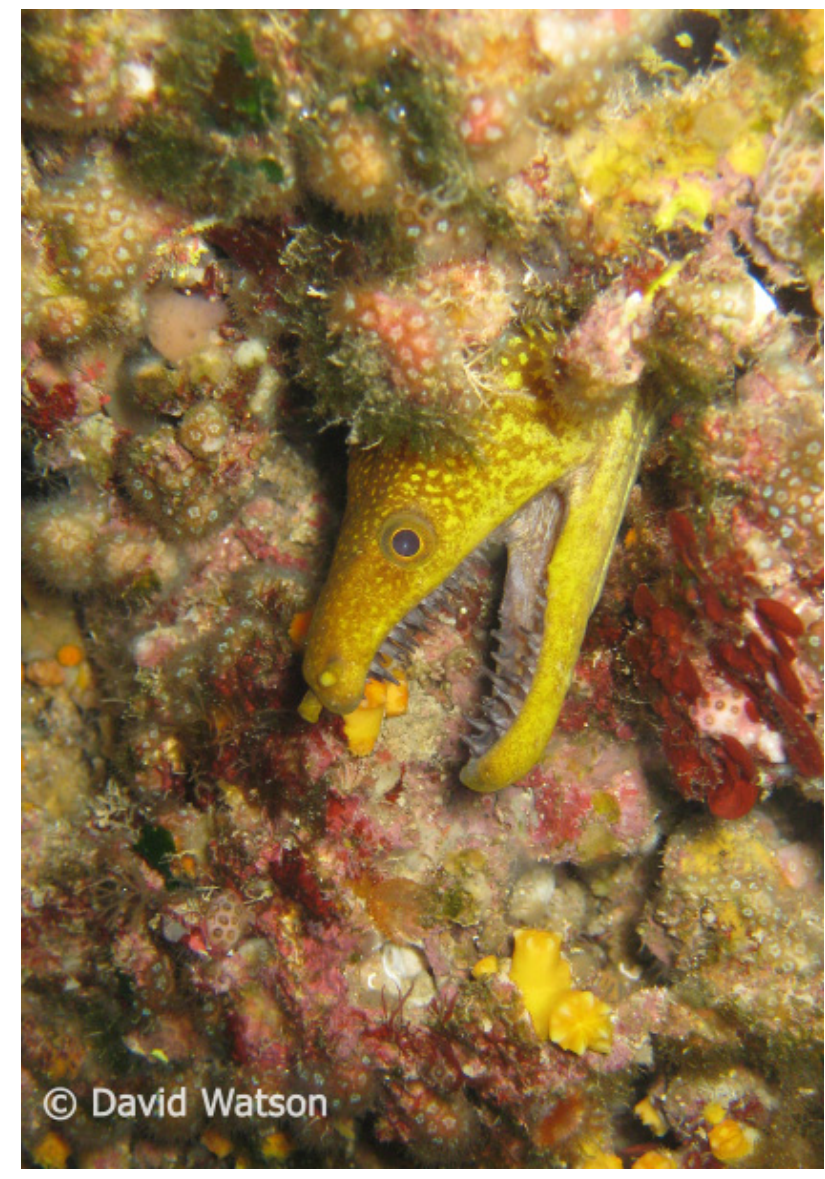

Fig. 1. The Enchelycore anatina individual observed within Maltese coastal waters, Central Mediterranean (photo by: David Watson)

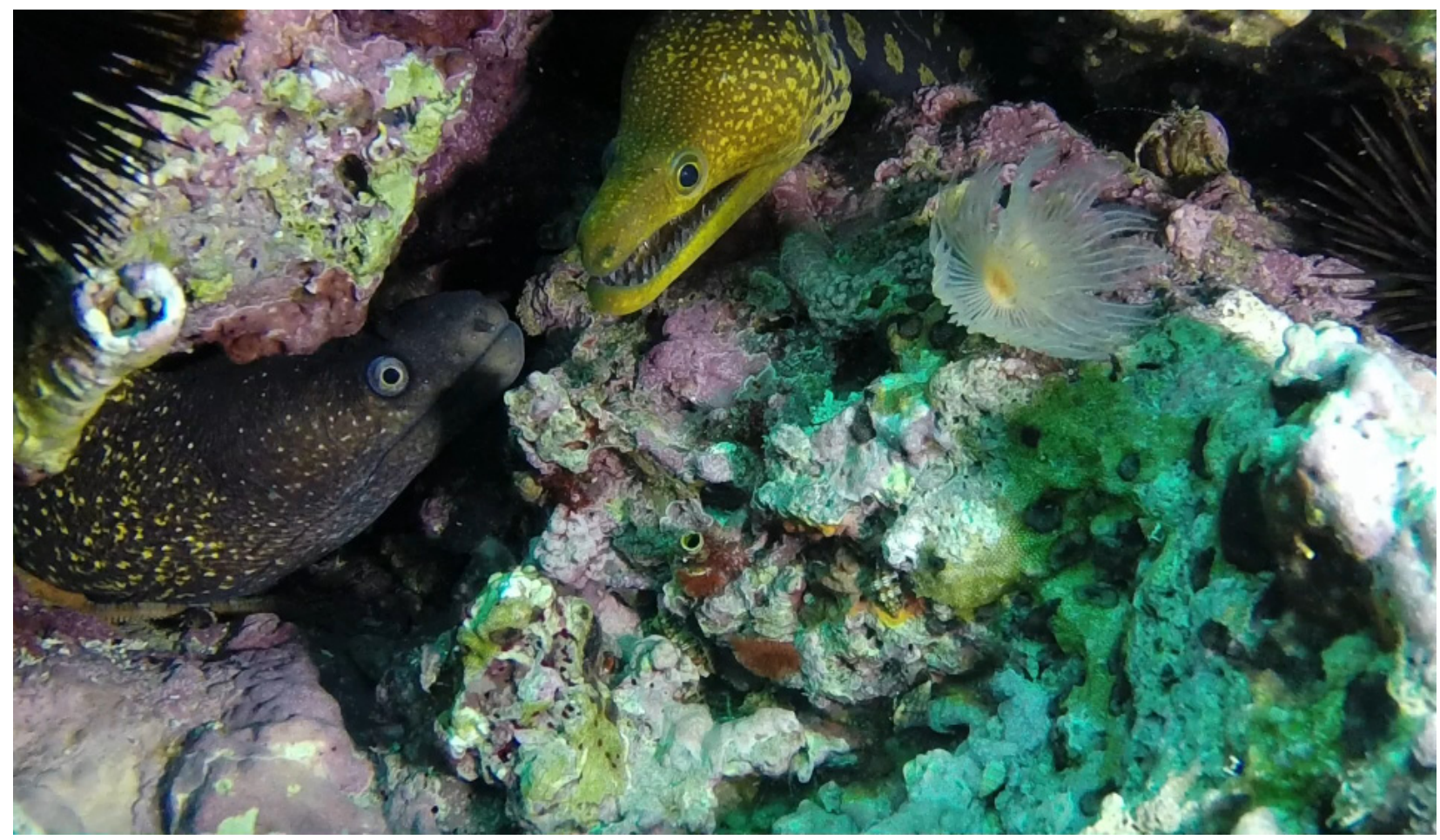

Fig. 2. Enchelycore anatina (right) and Muraena helena (left) observed in eastern Sicily (October 2014) (photo by: Gianfranco Mazza and Linda Pasolli) 
forth movements exhibited by $M$. helena, as if there was a sort of dominance behaviour by the former species versus the latter species in managing the co-occupied territory. The opposite behaviour was observed in eastern Sicily, where the most prudent fish was Enchelycore anatina, while $M$. helena showed familiarity with divers.

Cohabitation is documented between both conspecific and heterospecific morays of the genus Gymnothorax, as well as between morays and other organisms like spiny lobsters. Heterospecific aggregations seem more frequent than conspecific ones and would be possible thanks, inter alia, to food resource partitioning mechanisms (Lozano-Álvarez et al. 2010).

The record of Enchelycore anatina within the central Mediterranean given through this study marks the westernmost location within the Basin at which the species has been recorded to date. This record is also the umpteenth one for Atlantic ingressions of marine species within the Mediterranean, reaching as far eastwards as the Maltese coastal waters within the Sicily Channel in the Central Mediterranean. The most recent Atlantic species arrivals have been reported from the same waters by Castriota and Deidun (2014) and Deidun and Castriota (2014).

Unlike Lessepsian species, these ingressions are not considered as exotic or alien species but simply species which have expanded their natural range through non-anthropogenic means (Anonymous 2014). The study of the interactions between these range-expanding species and autochthonous ones deserves further study, as this might shed light on the potential of newcomers in modifying the ecological characteristics of the marine environment in question.

One may hypothesize that the westward expansion of non-indigenous marine species within the Mediterranean is mainly triggered by the warming up of waters within the same Basin, since the same phenomenon, known as meridionalisation, is being observed within the Mediterranean for indigenous marine species.

\section{ACKNOWLEDGEMENTS}

The authors are grateful to diver Antonio Anastasi for putting them in touch with David Watson.

\section{REFERENCES}

Anonymous 2014. Regulation (EU) No 1143/2014 of the European Parliament and of the council of 22 October 2014 on the prevention and management of the introduction and spread of invasive alien species. Official Journal of the European Union L 317/35.

Azzurro E., Ben Souissi J., Boughedir W., Castriota L., Deidun A., Falautano M., Ghanem R., Zammit-Mangion M., Andaloro F. 2014. The Sicily Strait: A transnational observatory for monitoring the advance of non-indigenous species. Biologia Marina Mediterranea 21 (1): 105-106.

Bauchot M.-L. 1987. Poissons osseux. Pp. 761-1530. In: Fischer W., Bauchot M.-L., Schneider M. (eds.) Fiches FAO d'identification des espèces pour les besoins de la pêche. (Révision 1). Méditerranée et mer Noire. Zone de pêche 37. Vol. 2. Vertébrés. FAO, Rome.
Ben-Tuvia A., Golani D. 1984. A west African fangtooth moray eel Enchelycore anatina from the Mediterranean coast of Israel. Copeia 1984 (2): 541-544. DOI: $10.2307 / 1445214$

Castriota L., Deidun A. 2014. First record of Pontinus kuhlii in Maltese waters. Marine Biodiversity Records 7: e2. DOI: $10.1017 / \mathrm{S} 1755267213001188$

Deidun A., Castriota L. 2014. First record of Abudefduf cfr saxatilis Linnaeus, 1758 (Perciformes: Pomacentridae) from the Maltese Islands (central Mediterranean). BioInvasions Records 3 (1): 53-56. DOI: 10.3391/bir.2014.3.1.10

Dulčić J., Dragičević B., Antolović N., Sulić-Šprem J., Kožul W., Grgičević R. 2014. Additional records of Lobotes surinamensis, Caranx crypsos, Enchelycore anatina, and Lagocephalus sceleratus (Actinopterygii) in the Adriatic Sea. Acta Ichthylogica et Piscatoria 44 (1): 71-74.

DOI: 10.3750/AIP2014.44.1.09

Guidetti P., Causio S., Licchelli C. 2012. The first record of Enchelycore anatina (Muraenidae: Pisces) in the Ionian Sea (Mediterranean basin). Marine Biodiversity Records 5: e22.

DOI: $10.1017 / \mathrm{S} 1755267212000164$

Katsanevakis S., Acar Ü., Ammar I., Balci B.A., Bekas P., Belmonte M., Chintiroglou C.C., Consoli P., Dimiza M., Fryganiotis K., Gerovasileiou V., Gnisci V., Gülşahin N., Hoffman R., Issaris Y., Izquierdo-Gomez D., Izquierdo- Muñoz A., Kavadas S., Koehler L., Konstantinidis E., Mazza G., Nowell G., Önal U., Özen M.R., Pafilis P., Pastore M., Perdikaris C., Poursanidis D., Prato E., Russo F., Sicuro B., Tarkan A.N., Thessalou-Legaki M., Tiralongo F., Triantaphyllou M., Tsiamis K., Tunçer S., Turan C., Türker A., Yapici S. 2014. New Mediterranean biodiversity records (October, 2014). Mediterranean Marine Science 15 (3): 675-695.

DOI: $10.12681 / \mathrm{mms} .1123$

Lipej L., Furlan B., Antolović N., Golani D., Dulčić J. 2011. The first record of fangtooth moray Enchelycore anatina (Lowe, 1839) in the Adriatic Sea. Journal of Applied Ichthyology 27 (6): 1387-1389.

DOI: $10.1111 /$ j.1439-0426.2011.01816.x

Lozano-Álvarez E., Briones-Fourzán P., Álvarez-Filip L., Weiss H.M., Negrete-Soto F., Barradas-Ortiz C. 2010. Influence of shelter availability on interactions between Caribbean spiny lobsters and moray eels: Implications for artificial lobster enhancement. Marine Ecology Progress Series 400: 175-185.

DOI: $10.3354 /$ meps 08324

Received: 24 December 2014 Accepted: 7 April 2015

Published electronically: 30 September 2015 